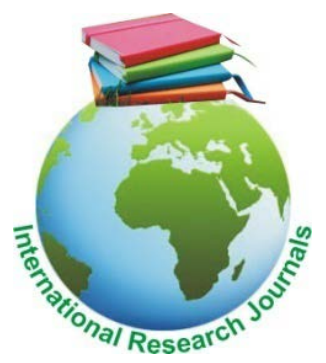

African Journal of Food Science and Technology (ISSN: 2141-5455) Vol. 9(4) pp. 74-83, Dec, 2018

DOI: http:/dx.doi.org/10.14303/ajfst.2018.239

Available online https://www.interesjournals.org/food-science-technology.html

Copyright (C2018 International Research Journals

Full Length Research Paper

\title{
Combined application of organic and inorganic fertilizers influenced biochemical qualities of fruit juice from yellow passion fruit (Passiflora edulis Deg.) genotypes
}

\author{
Ndukwe OO' ${ }^{*}$, Baiyeri KP ${ }^{2}$ \\ ${ }^{1}$ Department of Crop Science and Horticulture, Nnamdi Azikiwe University, Awka, Anambra State, Nigeria. \\ ${ }^{2}$ Department of Crop Science,University of Nigeria, Nsukka,Enugu,Nigeria. \\ *Corresponding Author Email: nduemeka26@yahoo.com
}

\begin{abstract}
Globally, the utilization of passion fruit juice is on the increase because of the organoleptic, tremendous nutritional and biochemical qualities which can be influenced by fertilization among other factors. Hence, the study investigated the influence of combined application of organic and inorganic fertilizers $(0,10,20$ t/ha PM, 5 t/ha PM+200 kg/ha NPK 15-15-15, 10 t/ha PM+200 kg/ha NPK 15-15-15 and $400 \mathrm{~kg} / \mathrm{ha}$ NPK 15-15-15) on the nutritional and biochemical qualities of fruit juice from two yellow passion genotypes ('Conventional' and KPF-4). Five matured, ripe and dropped fruits were directly picked under the yellow passion fruit vines which previously received the afore-mentioned fertilizers. Proximate and physicochemical compositions of fresh fruit juice from the fruits were assayed. Results were analyzed using split-plot design in completely randomized design, with genotype as main plot while fertilizer was assigned to sub-plots. Juice from Conventional genotype significantly $(\mathrm{p}<0.05)$ had highest crude fibre $(0.495 \%)$, moisture $(\mathbf{7 9 . 8 3 \% )}, \mathrm{K}$ $(2.61 \mathrm{mg} / 100 \mathrm{~mL})$ and $\mathrm{Na}(1.318 \mathrm{mg} / 100 \mathrm{~mL})$ with $10 \mathrm{t} / \mathrm{ha} \mathrm{PM}+200 \mathrm{~kg} / \mathrm{ha} \mathrm{NPK}$ application. Highest juice $\mathrm{pH}$ of 3.91 (less acidic level) and total titratable acidity $(8.223 \mathrm{mg} / 100 \mathrm{~mL})$ were also produced in Conventional genotype with the application of 10 t/ha PM+200 kg/ha NPK. On the other hand, highest total ash $(0.545 \%)$ and carbohydrate $(\mathbf{2 0 . 6 2} \%)$ in juice from KPF-4 genotype were recorded with the application of either 10 t/ha PM+200 kg/ha NPK or 5 t/ha PM+200 kg/ha NPK. The addition of 5 t/ha PM+200 kg/ha NPK produced highest calcium $(1469 \mathrm{mg} / 100 \mathrm{~mL})$ and iron $(97.49 \mathrm{mg} / 100 \mathrm{~mL})$ concentrations but vitamin $\mathrm{C}$ was highest with either the application of $20 \mathrm{t} / \mathrm{ha}$ PM $(29.04 \mathrm{mg} / 100 \mathrm{~mL})$ and $400 \mathrm{~kg} / \mathrm{ha} \mathrm{NPK}(29.33 \mathrm{mg} / 100$ $\mathrm{mL}$ ). Lowest crude protein, crude fibre, percentage moisture, $\mathrm{P}, \mathrm{K}, \mathrm{Na}$ and $\mathrm{Fe}$ concentrations were ascribed to fruits that received no fertilizer. Tannin, saponin and phytate compositions in the juice were reduced by the application of $10 \mathrm{t} / \mathrm{ha} P M$ or $400 \mathrm{~kg} / \mathrm{ha}, 10 \mathrm{t} / \mathrm{ha} \mathrm{PM}+200 \mathrm{~kg} / \mathrm{ha} \mathrm{NPK}$ and $10 \mathrm{t} / \mathrm{ha}$, respectively. The study therefore revealed that combined application of poultry manure and NPK fertilizers, especially $10 \mathrm{t} /$ ha PM+200 kg/ha NPK, can improve juice nutritional and biochemical qualities of yellow passion fruits. Further studies on the effect of other forms of organic and inorganic fertilizers combinations on juice qualities of passion fruit were recommended.
\end{abstract}

Keywords: Yellow passion fruit, Juice, Poultry manure, Proximate, Phytochemical.

\section{INTRODUCTION}

There is an increase in the consumption of fresh fruits and vegetables or their juices obviously because of the health benefits of these fruits and vegetables (Bhat and Stamminger, 2014; Simforian et al., 2015; Field survey). Passion fruit (Passiflora edulis Degener) which belongs to the family, Passifloraceae, is cultivated majorly because of the edible pulp and juice. The passion fruit can be freshly marketed and the pulp and juice consumed raw or as frozen pulps, jams, yoghurts (da Silva et al., 2015). The juice can also be blend with other fruits in wine and juice industries for the production of other products. Brazil is the world's largest producer of the crop. South Africa and 
Kenya ranks the topmost countries in Africa that cultivates the crop in commercial quantity.

Although, the crop is relatively known by few farmers in southeastern Nigeria, the juice is utilized in some fruit markets and smoothie outlets and stores. The distinct aroma and visual characteristics of the passion fruit juice are important for the marketing of the fruits (Abreu et al., 2009; da Silva et al., 2015). It is pertinent to understand the juice qualities when produced because of the nutritional and health benefits. However, the quality of crop produce is determined by pre and postharvest factors. Soil nutrition is one of these pre-harvest factors since plant roots absorb and translocate needed nutrients from the soil to the sinks (flowers, fruits, etc.). The application of fertilizer had been reported to influence the nutritional and biochemical properties of passion fruit juice (Ani and Baiyeri, 2008; Freire et al., 2014; Ndukwe and Baiyeri, 2016a). There is dearth of information on the influence of complementary application of organic and inorganic fertilizers on the biochemical qualities of juice from yellow passion fruit, especially the Conventional and KPF-4 (a hybrid breed in Nairobi, Kenya). Therefore, the objective of the study was to investigate the biochemical and nutritional qualities of fruit juice from two yellow passion fruit genotypes as influenced by the combined application of organic and inorganic fertilizers.

\section{MATERIALS AND METHODS}

Yellow passion fruits were obtained from an experimental field located in the teaching and research farm of the Department of Crop Science, University of Nigeria, Nsukka. Nsukka lies within longitude $07^{\circ} 29^{\prime} \mathrm{N}$ and latitude $06^{\circ} 51^{\prime} \mathrm{E}$ with $400 \mathrm{~m}$ above sea level. The total annual rainfall during the field study ranged between 1377 to $1555 \mathrm{~mm}$ with bimodal annual distribution. The average minimum and maximum temperatures were $21^{\circ} \mathrm{C}$ and $31^{\circ} \mathrm{C}$, respectively while the average relative humidity ranged between $52.7 \%$ to $61.7 \%$.

The experimental field which was established in 2016 involved two yellow passion fruit genotypes (Conventional and KPF-4) and six fertilizer treatments namely no fertilizer, $10 \mathrm{t} /$ ha Poultry Manure (PM), 20 t/ha PM, $5 \mathrm{t} /$ ha $P M+200 \mathrm{~kg} / \mathrm{ha}$ NPK, $10 \mathrm{t} / \mathrm{ha} P M+200 \mathrm{~kg} / \mathrm{ha}$ NPK, $400 \mathrm{~kg} / \mathrm{ha}$ NPK. NPK 15:15:15 fertilizer was used. These fertilizer treatments were applied at a month after transplanting. The experimental layout was split-plot laid out in completely randomized design replicated three times. The main plot was the two genotypes while the subplot was the fertilizer treatments. Five passion fruit vines in a single row were staked with the aid of two wooden poles ( $2 \mathrm{~m}$ high) placed at the end of each row with the help of horizontal rope connecting the wooden poles. Other cultural practices was as described by Ndukwe and Baiyeri (2016b).

Five fresh passion fruits were picked according to the treatment and treatment combinations. They were sent to the laboratory for biochemical and nutritional analyses. The proximate composition (crude protein, crude fibre, crude fat, total ash, moisture, carbohydrate), physicochemical qualities $(\mathrm{pH}$, total soluble solid, total titratable acidity, ${ }^{\circ}$ Brix, vitamins $\mathrm{A}$ and $\mathrm{C}$ ), mineral concentrations (phosphorus $(\mathrm{P})$, potassium $(\mathrm{K})$, nitrogen $(\mathrm{N})$, calcium (Ca), magnesium (Mg), zinc ( $\mathrm{Zn})$, iron (Fe), sodium ( $\mathrm{Na})$ ), physicochemical characteristics and phytochemical composition (phenol, saponin, tannin, oxalate, phytate) were analysed in quadruplicates. Generally, the protocols of AOAC (2005) were adopted except the determination of phytate content which followed Maga (1982) procedure (Table 1).

The results recorded were subjected to analysis of variance following the procedure outlined for split-plot experiment in completely randomized design using GENSTAT (2007). Separation of treatment means were done using Least Significant Difference (LSD) at 5\% level of significant.

\section{STATISTICAL ANALYSIS}

The results recorded were subjected to analysis of variance following the procedure outlined for split-plot experiment in completely randomized design using GENSTAT (2007). Separation of treatment means were done using Least Significant Difference (LSD) at 5\% level of significant.

Table 1. Physicochemical characteristics of composite soil sample of the experimental site and poultry manure used during the studies.

\begin{tabular}{|c|c|c|}
\hline Soil properties & Top soil $(0-20 \mathrm{~cm})$ & Poultry manure \\
\hline \multicolumn{3}{|l|}{ Physical properties } \\
\hline $\mathrm{pH}\left(\mathrm{H}_{2} \mathrm{O}\right)$ & 5.7 & 8.1 \\
\hline \multicolumn{3}{|l|}{$\mathrm{pH}(\mathrm{KCl})$} \\
\hline Organic carbon (\%) & 1.39 & 13.95 \\
\hline Organic matter (\%) & 2.06 & 24.06 \\
\hline Sand (\%) & 85 & - \\
\hline Silt (\%) & 9 & - \\
\hline Clay (\%) & 6 & - \\
\hline Textural class & Sandy loam & - \\
\hline \multicolumn{3}{|l|}{ Chemical properties } \\
\hline Nitrogen (\%) & 0.13 & 3.64 \\
\hline $\begin{array}{l}\text { Available phosphorus } \\
\text { (ppm) }\end{array}$ & 8.39 & $0.39(\%)$ \\
\hline Potassium (meq/100 g) & 0.11 & 3.88 \\
\hline Calcium (meq/100 g) & 8.8 & 28.4 \\
\hline $\begin{array}{l}\text { Magnesium(meq/100 } \\
\text { g) }\end{array}$ & 1.2 & 12.2 \\
\hline Sodium (meq/100 g) & 0.07 & 1.72 \\
\hline $\begin{array}{l}\text { Cation exchangeable } \\
\text { capacity (meq/100 g) }\end{array}$ & 16 & - \\
\hline Base saturation (\%) & 63.63 & - \\
\hline $\mathrm{Al}^{3+}(\mathrm{meq} / 100 \mathrm{~g})$ & Trace & - \\
\hline $\mathrm{H}^{+}($meq $/ 100 \mathrm{~g})$ & 1.4 & - \\
\hline
\end{tabular}




\section{RESULT}

\section{Proximate Composition of Fruit Juice}

The proximate compositions of the juice were significantly influenced by genotype and fertilizer interactions (Figures 1 and 2). The highest mean value of crude protein (1.49\%) was recorded by the juice of Conventional genotype with $400 \mathrm{~kg} / \mathrm{ha}$ NPK. This did not significantly differ with the mean value $(1.47 \%)$ obtained from the application of $5 \mathrm{t} /$ ha PM+200 kg/ha NPK. Crude fat $(0.79 \%)$ was highest in KPF-4 with no fertilizer application. The percentage juice crude fibre $(0.495 \%)$ and moisture content $(79.83 \%)$ were significantly $(p<0.05)$ highest in the conventional with combined application of $10 \mathrm{t} / \mathrm{ha} \mathrm{PM}+200 \mathrm{~kg} / \mathrm{ha}$ NPK. The juice total ash (0.545\%) and carbohydrate (20.62\%) were also highest in KPF-4 with complementary application of $10 \mathrm{t} / \mathrm{ha} \mathrm{PM}+200 \mathrm{~kg} / \mathrm{ha} \mathrm{NPK}$ and $5 \mathrm{t} / \mathrm{ha} \mathrm{PM+200} \mathrm{kg/ha}$ NPK.

\section{Mineral Concentrations of Fruit Juice}

Higher juice $\mathrm{P}, \mathrm{K}, \mathrm{Ca}$ and $\mathrm{Zn}$ concentrations were obtained from the Conventional than the KPF-4 (Table 2). Fertilizer application influenced the juice $\mathrm{P}, \mathrm{K}, \mathrm{Ca}, \mathrm{Na}$ and $\mathrm{Zn}$ concentrations (Table 3). The application of 400 $\mathrm{kg} / \mathrm{ha} \mathrm{NPK}$ produced juice with highest concentrations of $\mathrm{P}(103.51 \mathrm{mg} / 100 \mathrm{~mL})$ while $\mathrm{K}(2.61 \mathrm{mg} / 100 \mathrm{~mL})$ and $\mathrm{Na}(1.318 \mathrm{mg} / 100 \mathrm{~mL})$ contents were highest with complementary application of $10 \mathrm{t} / \mathrm{ha} \mathrm{PM}+200 \mathrm{~kg} / \mathrm{ha}$
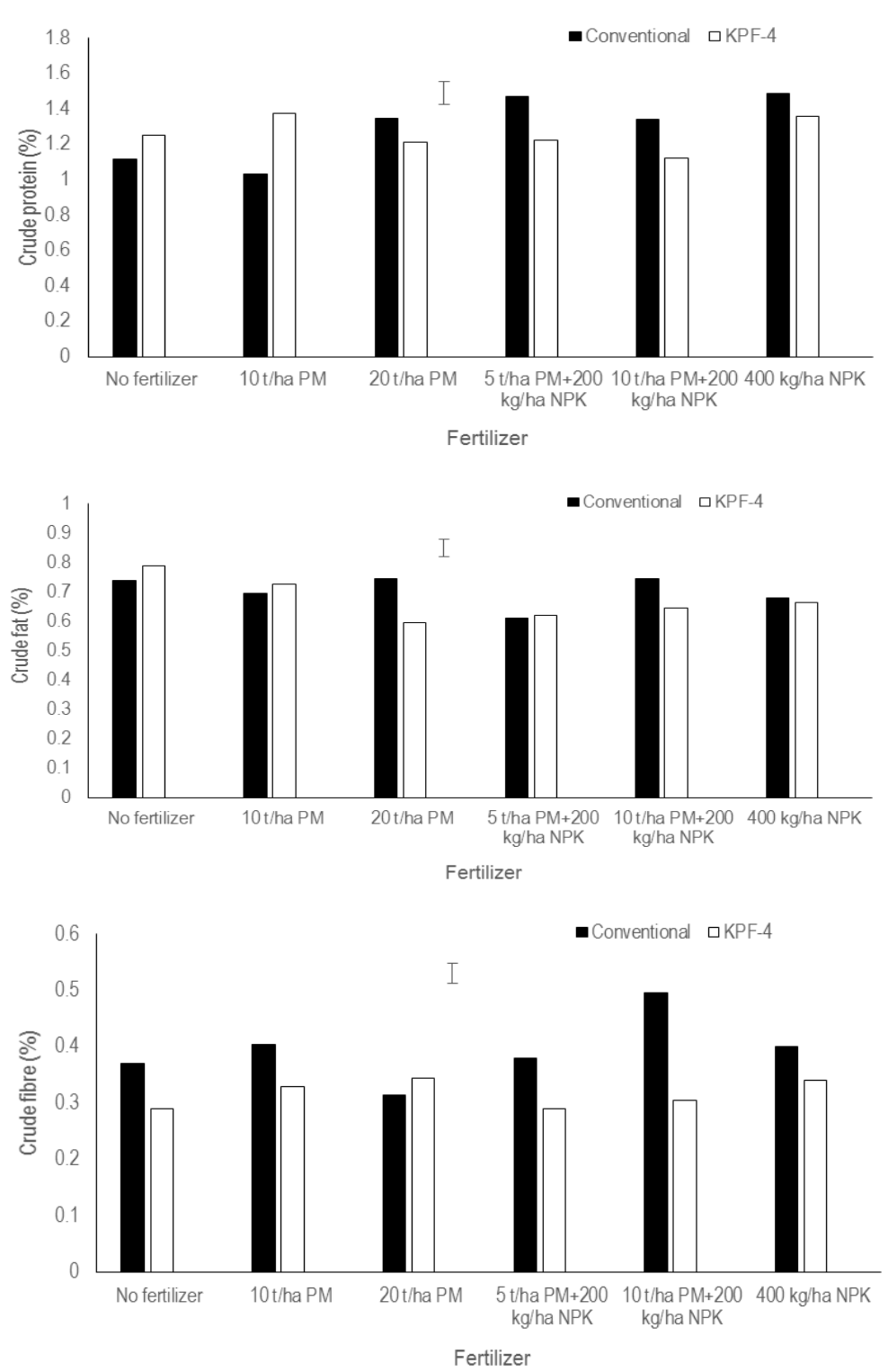

Figure 1. Effect of genotype and fertilizer interaction on (a) Crude protein (b) Crude fat and (c) Crude fibre of juice from yellow passion fruit genotypes. Vertical bar=Least significant difference value. 

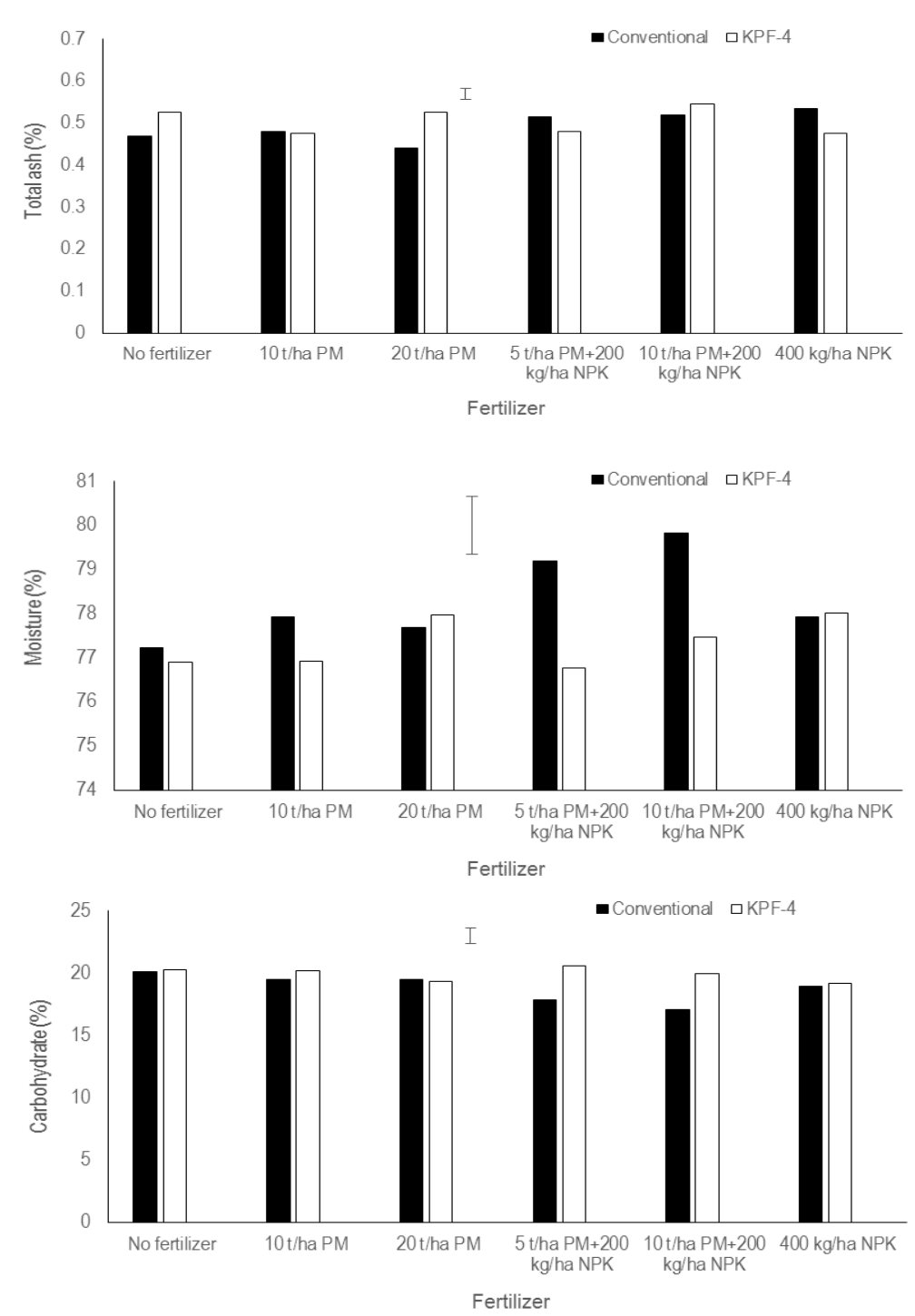

Figure 2. Effect of genotype and fertilizer interaction on (a) total ash (b) percentage moisture and (c) carbohydrate of juice from yellow passion fruit genotypes. Vertical bar=Least significant difference value.

Table 2. Main effects of genotype and fertilizer on mineral concentrations of yellow passion fruit juice as influenced by organic and inorganic fertilizers

\begin{tabular}{|c|c|c|c|c|c|c|c|}
\hline \multicolumn{8}{|c|}{ Mineral concentrations in $\mathrm{mg} / 100 \mathrm{~mL}$} \\
\hline Genotype & $\mathrm{P}$ & $\mathrm{K}$ & $\mathrm{Ca}$ & $\mathrm{Mg}$ & $\mathrm{Na}$ & $\mathrm{Fe}$ & $\mathrm{Zn}$ \\
\hline KPF-4 & 91.19 & 1.78 & 1062 & 1748 & 1.275 & 90.14 & 1083 \\
\hline LSD 0.05 & 1.24 & 0.05 & 20.6 & Ns & ns & ns & 21.51 \\
\hline No fertilizer & 95.79 & 1.3 & 1131 & 1738.9 & 1.235 & 90.13 & 1106.3 \\
\hline 10 t/ha PM & 102.23 & 1.69 & 1334 & 1901.3 & 1.255 & 95.18 & 1087.7 \\
\hline 20 t/ha PM & 99.91 & 2.11 & 924 & 1897.4 & 1.31 & 94.43 & 1165.3 \\
\hline $5 \mathrm{t} / \mathrm{ha} \mathrm{PM}+200 \mathrm{~kg} / \mathrm{ha}$ NPK & 97.74 & 2.02 & 1469 & 1679.8 & 1.24 & 97.49 & 1131.2 \\
\hline 10 t/ha PM+200 kg/ha NPK & 96.17 & 2.61 & 919 & 1511.3 & 1.318 & 83.6 & 1033 \\
\hline $400 \mathrm{~kg} / \mathrm{ha}$ NPK & 103.51 & 1.81 & 767 & 1533.5 & 1.298 & 84.42 & 1118.7 \\
\hline
\end{tabular}


NPK application. Calcium (1469 mg/100 mL) and iron $(97.49 \mathrm{mg} / 100 \mathrm{~mL}$ ) concentrations were highest with 5 t/ha PM+200 kg/ha NPK, whereas highest Mg (1901.3 $\mathrm{mg} / 100 \mathrm{~mL}$ ) and $\mathrm{Zn}(1165.3 \mathrm{mg} / 100 \mathrm{~mL})$ concentrations were recorded with the addition of 10 and $20 \mathrm{t} /$ ha poultry manure, respectively.

The interaction of genotype and fertilizer indicated that $\mathrm{P}$ concentration was highest in the juice of Conventional genotype with either no fertilizer or $10 \mathrm{t} / \mathrm{ha}$ poultry manure application (Table 3). However, $\mathrm{K}, \mathrm{Ca}, \mathrm{Fe}, \mathrm{Na}$ and $\mathrm{Zn}$ concentrations were highest in juice of Conventional genotype with $10 \mathrm{t} / \mathrm{ha} \mathrm{PM}+200 \mathrm{~kg} / \mathrm{ha} \mathrm{NPK}, 10 \mathrm{t} / \mathrm{ha}$ PM, $5 \mathrm{t} / \mathrm{ha} \mathrm{PM}+200 \mathrm{~kg} / \mathrm{ha}$ NPK and $400 \mathrm{~kg} / \mathrm{ha}$ NPK applications, respectively.

\section{Juice $\mathrm{pH}$, Total Soluble Solid, Titratable Acidity, Vitamins $A$ and $C$ Compositions of the Fruit Juice}

The acidic level of the juice was found to be significantly lower in the Conventional (3.034) than in KPF-4 (2.943) (Table 4). But the juice vitamin A content (1.818 ug/100 $\mathrm{mL})$ was higher in KPF-4 while vitamin C $(27.797 \mathrm{mg} / 100$ $\mathrm{mL}$ ) was higher in the Conventional than KPF-4 genotype.
Fertilizer application influenced the juice $\mathrm{pH}$, total soluble solid, titratable acidity, vitamins $\mathrm{A}$ and $\mathrm{C}$ compositions (Table 4). The lowest juice acidic level was recorded with the application of $10 \mathrm{t} /$ ha poultry manure which also produced highest total soluble solid (3.158). Similarly, the complementary application of $10 \mathrm{t} / \mathrm{ha} \mathrm{PM}+200 \mathrm{~kg} /$ ha NPK produced highest total titratable acidity $(8.223$ $\mathrm{mg} / 100 \mathrm{~mL}$ ) in the juice while vitamin $\mathrm{C}$ was highest with either the application of $20 \mathrm{t} / \mathrm{ha}$ PM $(29.04 \mathrm{mg} / 100 \mathrm{~mL})$ and $400 \mathrm{~kg} / \mathrm{ha}$ NPK $(29.33 \mathrm{mg} / 100 \mathrm{~mL})$.

The combined effect of genotype and fertilizer revealed that the application of $10 \mathrm{t} / \mathrm{ha} \mathrm{PM}+200 \mathrm{~kg} / \mathrm{ha} \mathrm{NPK}$ produced lowest juice acidity (3.91) in Conventional genotype and highest total titratable acidity $(8.57 \mathrm{mg} / 100 \mathrm{~mL})$ in KPF-4 genotype (Table 5). The application of $10 \mathrm{t} / \mathrm{ha} \mathrm{PM}$ produced highest total soluble solid $(17.755 \mathrm{mg} / 100 \mathrm{~mL}$ ) in the Conventional genotype. Highest vitamin C (29.88 mg/100 $\mathrm{mL}$ ) was also produced in Conventional genotype when 400 $\mathrm{kg} / \mathrm{ha}$ NPK was applied. When no fertilizer was applied, KPF4 juice had highest vitamin A (1.975 ug/100 mL).

\section{Phytochemical Composition of Fruit Juice}

All the phytochemical compositions were not significantly

Table 3. Interaction effect of genotype and fertilizer on mineral concentrations of yellow passion fruit juice as influenced by organic and inorganic fertilizers

\begin{tabular}{|c|c|c|c|c|c|c|c|c|}
\hline \multicolumn{9}{|c|}{ Mineral concentrations in $\mathrm{mg} / 100 \mathrm{~mL}$} \\
\hline Genotype & Fertilizer & $\mathbf{P}$ & $\mathbf{K}$ & $\mathrm{Ca}$ & Mg & $\mathrm{Na}$ & $\mathrm{Fe}$ & $\mathrm{Zn}$ \\
\hline \multirow[t]{6}{*}{ Conventional } & No fertilizer & 114.84 & 1.52 & 1224 & 1790.3 & 1.235 & 78.27 & 1106.9 \\
\hline & 10 t/ha PM & 114.66 & 1.79 & 1615 & 1968.7 & 1.25 & 94.91 & 1100 \\
\hline & 20 t/ha PM & 106.03 & 2.57 & 706 & 1790.7 & 1.305 & 98.8 & 1190.1 \\
\hline & $5 \mathrm{t} / \mathrm{ha} \mathrm{PM}+200 \mathrm{~kg} / \mathrm{ha}$ NPK & 105.31 & 1.64 & 1388 & 1559.6 & 1.23 & 103.12 & 1129.8 \\
\hline & $10 \mathrm{t} / \mathrm{ha} \mathrm{PM}+200 \mathrm{~kg} / \mathrm{ha}$ NPK & 98.55 & 2.77 & 961 & 1427.2 & 1.315 & 83.73 & 996.8 \\
\hline & $400 \mathrm{~kg} / \mathrm{ha}$ NPK & 104.18 & 2.08 & 823 & 1500 & 1.32 & 90.86 & 1262.8 \\
\hline \multirow[t]{6}{*}{ KPF-4 } & No fertilizer & 76.74 & 1.08 & 1039 & 1687.5 & 1.235 & 102 & 1105.8 \\
\hline & 10 t/ha PM & 89.8 & 1.59 & 1053 & 1833.8 & 1.26 & 95.45 & 1075.5 \\
\hline & 20 t/ha PM & 93.78 & 1.66 & 1142 & 2004.1 & 1.315 & 9007 & 1140.5 \\
\hline & $5 \mathrm{t} / \mathrm{ha} \mathrm{PM}+200 \mathrm{~kg} / \mathrm{ha}$ NPK & 90.17 & 2.4 & 1550 & 1800 & 1.25 & 91.86 & 1129.8 \\
\hline & 10 t/ha PM+200 kg/ha NPK & 93.8 & 2.45 & 877 & 1595.4 & 1.32 & 83.47 & 996.8 \\
\hline & $400 \mathrm{~kg} / \mathrm{ha}$ NPK & 102.83 & 1.54 & 712 & 1567 & 1.275 & 77.99 & 974.6 \\
\hline LSD0.05 & & 1.27 & 0.07 & 117.8 & 77.9 & 0.021 & 5.2 & 39.25 \\
\hline
\end{tabular}

Table 4. Main effects of genotype and fertilizer on $\mathrm{pH}$, total soluble solid, total titratable acidity, ${ }^{\circ}$ brix, vitamins $\mathrm{A}$ and $\mathrm{C}$ of yellow passion fruit juice as influenced by organic and inorganic fertilizers

\begin{tabular}{|c|c|c|c|c|c|c|}
\hline Genotype & $\mathrm{pH}\left(\mathrm{H}_{2} \mathrm{O}\right)$ & $\begin{array}{c}\text { Total soluble solid (mg/100 } \\
\mathrm{mL})\end{array}$ & $\begin{array}{l}\text { Total titratable acidity } \\
(\mathrm{mg} / 100 \mathrm{~mL})\end{array}$ & ${ }^{\circ}$ Brix & $\begin{array}{c}\text { Vitamin A (ug/100 } \\
\mathrm{mL} \text { ) }\end{array}$ & $\begin{array}{c}\text { Vitamin C } \\
(\mathrm{mg} / 100 \mathrm{~mL})\end{array}$ \\
\hline Conventional & 3.034 & 15.535 & 6.743 & 9.865 & 1.613 & 27.797 \\
\hline KPF-4 & 2.943 & 15.522 & 6.865 & 9.841 & 1.818 & 26.206 \\
\hline LSD 0.05 & 0.025 & ns & ns & ns & 0.021 & 0.896 \\
\hline \multicolumn{7}{|l|}{ Fertilizer } \\
\hline No fertilizer & 2.94 & 15.388 & 5.93 & 9.903 & 1.915 & 25.42 \\
\hline 10 t/ha PM & 3.158 & 19.73 & 6.137 & 9.868 & 1.778 & 25.435 \\
\hline 20 t/ha PM & 2.945 & 14.505 & 6.76 & 9.833 & 1.712 & 29.04 \\
\hline $\begin{array}{l}5 \mathrm{t} / \mathrm{ha} \mathrm{PM}+200 \mathrm{~kg} / \mathrm{ha} \\
\text { NPK }\end{array}$ & 3.123 & 12.783 & 6.053 & 9.818 & 1.71 & 27.48 \\
\hline $\begin{array}{l}10 \mathrm{t} / \mathrm{ha} \mathrm{PM}+200 \mathrm{~kg} / \mathrm{ha} \\
\text { NPK }\end{array}$ & 2.923 & 15.68 & 8.223 & 9.848 & 1.583 & 25.303 \\
\hline 400 kg/ha NPK & 2.843 & 15.128 & 7.722 & 9.85 & 1.597 & 29.33 \\
\hline LSD 0.05 & 0.029 & 0.6 & 0.154 & ns & 0.076 & 0.556 \\
\hline
\end{tabular}


Table 5. Interaction effect of genotype and fertilizer on $\mathrm{pH}$, total soluble solid, total titratable acidity, ${ }^{\circ}$ brix, vitamins $\mathrm{A}$ and $\mathrm{C}$ of yellow passion fruit juice as influenced by organic and inorganic fertilizers

\begin{tabular}{|c|c|c|c|c|c|c|c|}
\hline Genotype & Fertilizer & $\mathrm{pH}\left(\mathrm{H}_{2} \mathrm{O}\right)$ & $\begin{array}{l}\text { Total soluble solid } \\
(\mathrm{mg} / 100 \mathrm{~mL})\end{array}$ & $\begin{array}{l}\text { Total titratable acidity } \\
(\mathrm{mg} / 100 \mathrm{~mL})\end{array}$ & ${ }^{\circ}$ Brix & $\begin{array}{c}\text { Vitamin } \\
\text { A (ug/100 mL) }\end{array}$ & $\begin{array}{c}\text { Vitamin C } \\
(\mathrm{mg} / 100 \mathrm{~mL})\end{array}$ \\
\hline \multirow[t]{6}{*}{ Conventional } & No fertilizer & 3.065 & 13.82 & 5.21 & 9.915 & 1.855 & 26.175 \\
\hline & 10 t/ha PM & 3.195 & 19.755 & 6.095 & 9.865 & 1.875 & 27.815 \\
\hline & 20 t/ha PM & 2.99 & 17.265 & 6.95 & 9.84 & 1.525 & 28.4 \\
\hline & $5 \mathrm{t} / \mathrm{ha} \mathrm{PM+200} \mathrm{kg/ha} \mathrm{NPK}$ & 3.155 & 12.885 & 6.26 & 9.84 & 1.72 & 28.885 \\
\hline & $10 \mathrm{t} / \mathrm{ha} \mathrm{PM}+200 \mathrm{~kg} / \mathrm{ha}$ NPK & 3.91 & 13.88 & 7.875 & 9.825 & 1.37 & 25.625 \\
\hline & $400 \mathrm{~kg} / \mathrm{ha} \mathrm{NPK}$ & 2.89 & 15.69 & 8.07 & 9.905 & 1.335 & 29.88 \\
\hline \multirow[t]{6}{*}{ KPF-4 } & No fertilizer & 2.815 & 16.955 & 6.65 & 9.89 & 1.975 & 24.665 \\
\hline & 10 t/ha PM & 3.12 & 19.705 & 6.18 & 9.87 & 1.68 & 23.055 \\
\hline & 20 t/ha PM & 2.9 & 11.745 & 6.57 & 9.825 & 1.9 & 29.68 \\
\hline & 5 t/ha PM+200 kg/ha NPK & 3.09 & 12.68 & 2.845 & 9.795 & 1.7 & 26.075 \\
\hline & $10 \mathrm{t} / \mathrm{ha} \mathrm{PM}+200 \mathrm{~kg} / \mathrm{ha} \mathrm{NPK}$ & 2.935 & 17.48 & 8.57 & 9.87 & 1.795 & 24.98 \\
\hline & $400 \mathrm{~kg} / \mathrm{ha}$ NPK & 2.795 & 14.565 & 7.375 & 9.795 & 1.86 & 28.78 \\
\hline LSD 0.05 & & 0.04 & 0.84 & 0.254 & Ns & 0.099 & 0.853 \\
\hline
\end{tabular}

Table 6. Main effects of genotype and fertilizer on phytochemical composition of yellow passion fruit juice as influenced by organic and inorganic fertilizers

\begin{tabular}{|l|c|c|c|c|c|}
\hline Genotype & $\begin{array}{c}\text { Tannin } \\
(\mathbf{m g} / \mathbf{1 0 0} \mathbf{~ m L})\end{array}$ & $\begin{array}{c}\text { Saponin } \\
(\mathbf{m g} / \mathbf{1 0 0} \mathbf{~ m L})\end{array}$ & $\begin{array}{c}\text { Phytate } \\
(\mathbf{m g} / \mathbf{1 0 0} \mathbf{~ m L})\end{array}$ & $\begin{array}{c}\text { Oxalate } \\
(\mathbf{m g} / \mathbf{1 0 0} \mathbf{~ m L})\end{array}$ & $\begin{array}{c}\text { Phenol } \\
(\mathbf{m g} / \mathbf{1 0 0} \mathbf{~ m L})\end{array}$ \\
\hline Conventional & 0.042 & 1.018 & 0.29 & 0.188 & 0.094 \\
\hline KPF-4 & 0.041 & 0.982 & 0.293 & 0.202 & 0.095 \\
\hline LSD0.05 & $\mathrm{ns}$ & $\mathrm{ns}$ & $\mathrm{Ns}$ & $\mathrm{ns}$ & $\mathrm{ns}$ \\
\hline Fertilizer & \multicolumn{5}{|l|}{} \\
\hline No fertilizer & 0.044 & 0.96 & 0.273 & 0.175 & 0.09 \\
\hline 10 t/ha PM & 0.039 & 1.06 & 0.258 & 0.178 & 0.098 \\
\hline 20 t/ha PM & 0.041 & 1.064 & 0.345 & 0.218 & 0.092 \\
\hline 5 t/ha PM+200 kg/ha NPK & 0.041 & 0.994 & 0.283 & 0.193 & 0.098 \\
\hline 10 t/ha PM+200 kg/ha NPK & 0.044 & 0.908 & 0.308 & 0.205 & 0.094 \\
\hline $400 \mathrm{~kg} / \mathrm{ha} \mathrm{NPK}$ & 0.039 & 1.016 & 0.283 & 0.2 & 0.095 \\
\hline LS D0.05 & 0.001 & 0.023 & 0.018 & 0.01 & 0.006 \\
\hline
\end{tabular}

Table 7: Interaction effect of genotype and fertilizer on phytochemical composition of yellow passion fruit juice as influenced by organic and inorganic fertilizers

\begin{tabular}{|c|c|c|c|c|c|c|}
\hline Genotype & Fertilizer & $\begin{array}{c}\text { Tannin } \\
(\mathrm{mg} / 100 \mathrm{~mL})\end{array}$ & $\begin{array}{c}\text { Saponin } \\
(\mathrm{mg} / 100 \mathrm{~mL})\end{array}$ & $\begin{array}{c}\text { Phytate } \\
\text { (mg/100 mL) }\end{array}$ & $\begin{array}{c}\text { Oxalate } \\
(\mathrm{mg} / 100 \mathrm{~mL})\end{array}$ & $\begin{array}{c}\text { Phenol } \\
(\mathrm{mg} / 100 \mathrm{~mL})\end{array}$ \\
\hline \multirow[t]{6}{*}{ Conventional } & No fertilizer & 0.05 & 0.91 & 0.265 & 0.205 & 0.081 \\
\hline & 10 t/ha PM & 0.033 & 1.029 & 0.235 & 0.165 & 0.098 \\
\hline & 20 t/ha PM & 0.04 & 1.099 & 0.37 & 0.2 & 0.086 \\
\hline & 5 t/ha PM+200 kg/ha NPK & 0.036 & 1.058 & 0.23 & 0.15 & 0.105 \\
\hline & 10 t/ha PM+200 kg/ha NPK & 0.05 & 0.966 & 0.315 & 0.19 & 0.1 \\
\hline & 400 kg/ha NPK & 0.042 & 1.049 & 0.325 & 0.215 & 0.092 \\
\hline \multirow[t]{6}{*}{ KPF-4 } & No fertilizer & 0.039 & 1.01 & 0.28 & 0.145 & 0.099 \\
\hline & 10 t/ha PM & 0.045 & 1.092 & 0.28 & 0.19 & 0.097 \\
\hline & 20 t/ha PM & 0.043 & 1.03 & 0.32 & 0.235 & 0.098 \\
\hline & 5 t/ha PM+200 kg/ha NPK & 0.045 & 0.851 & 0.335 & 0.22 & 0.105 \\
\hline & 10 t/ha PM+200 kg/ha NPK & 0.039 & 0.93 & 0.3 & 0.235 & 0.1 \\
\hline & 400 kg/ha NPK & 0.037 & 0.984 & 0.24 & 0.185 & 0.097 \\
\hline LSD0.05 & & 0.001 & 0.049 & 0.023 & 0.024 & 0.008 \\
\hline
\end{tabular}

different between the genotypes (Table 6). Fertilizer, however, had significant influence on all the phytochemical compositions of the juice (Table 6). The juice tannin $(0.044$ $\mathrm{mg} / 100 \mathrm{~mL}$ ) was significantly highest when either $10 \mathrm{t} / \mathrm{ha}$ $\mathrm{PM}+200 \mathrm{~kg} / \mathrm{ha}$ NPK was applied or when no fertilizer was applied. The lowest tannin content was observed when either $10 \mathrm{t} / \mathrm{ha}$ poultry manure or $400 \mathrm{~kg} / \mathrm{ha}$ NPK were applied. The application of $20 \mathrm{t} / \mathrm{ha}$ PM resulted in highest juice concentration of saponin (1.064 mg/100 mL), phytate $(0.345 \mathrm{mg} / 100 \mathrm{~mL})$ and oxalate $(0.218 \mathrm{mg} / 100$ $\mathrm{mL})$. However, phenol composition was highest with either 10 t/ha PM or 5 t/ha PM+200 kg/ha NPK.

Genotype and fertilizer interaction showed that the application of $10 \mathrm{t} / \mathrm{ha} \mathrm{PM}+200 \mathrm{~kg} / \mathrm{ha}$ NPK gave highest juice tannin concentration in the Conventional (0.05 $\mathrm{mg} / 100 \mathrm{~mL}$ ) (Table 7). The phenol concentration was 
highest also in the Conventional with either $5 \mathrm{t} / \mathrm{ha}$ $\mathrm{PM}+200 \mathrm{~kg} / \mathrm{ha}$ NPK $(0.105 \mathrm{mg} / 100 \mathrm{~mL})$ or $10 \mathrm{t} / \mathrm{ha}$ $\mathrm{PM}+200 \mathrm{~kg} / \mathrm{ha}$ NPK $(0.100 \mathrm{mg} / 100 \mathrm{~mL})$ application. The fruit juice of Conventional genotype that received $20 \mathrm{t} / \mathrm{ha}$ PM had highest concentration of saponin $(1.099 \mathrm{mg} / 100$ $\mathrm{mL}$ ) and phytate $(0.37 \mathrm{mg} / 100 \mathrm{~mL})$. On the other hand, highest oxalate composition was observed in KPF-4 juices when their fruits received either $20 \mathrm{t} / \mathrm{ha}$ PM or $10 \mathrm{t} / \mathrm{ha}$ $\mathrm{PM}+200 \mathrm{~kg} / \mathrm{ha}$ NPK.

\section{DISCUSSION}

The proximate compositions of the two genotypes were relatively similar except the crude fat and fibre contents. Earlier reports (Ndukwe and Baiyeri, 2016a,b) on the growth, fruit yield and juice biochemical qualities of the two genotypes in the same study area indicated that the genotypes could be genetically related. It will be pertinent to characterize the Conventional genotype so that genetic comparisons with the hybrid, KPF-4 could be elucidated.

The juice moisture contents of both genotypes (78.29\% and $\mathbf{7 7 . 3 4 \%}$ for Conventional and KPF-4, respectively) were comparatively high. The passion fruit is reported to be rich in water (Orjuela et al., 2011) with range of about 55.7\% to $90 \%$ moisture contents (Rodríguez and García, 2010). The fruits could serve as good sources of rehydrating the body and quenching thirst. The moisture contents $(85.57$ to $86.33 \%$ ) reported by Ani and Baiyeri (2008) as well as Ogbonna et al. (2013) in orange (85.85\%), pineapple (83.99\%) and pawpaw (82.74\%) juices are comparable to the values obtained in this study.

The concentrations of the minerals in the juice from both passion fruit genotypes indicated that the fruit juice possessed considerable amount of minerals which falls within the recommended rates required by humans per day. For instance, the Adequate Intake (Al) for Ca ranges from 500 to $1200 \mathrm{mg}$ day-1 while the Recommended Dietary Allowance (RDA) for P ranges from 460 to 700 $\mathrm{mg} /$ day (National Academy of Sciences, 2005).

The $\mathrm{pH}$ range (2.94 and 3.03) agreed with the standards of identity and quality for passion fruit pulp, given between 2.7 and 3.8 (Brasil, 2000). The value of total soluble solid reported in this work (12.78 to $19.73 \mathrm{mg} / 100 \mathrm{~mL}$ ), titratable acidity (5.93 to $8.22 \mathrm{mg} / 100 \mathrm{~mL}$ ), vitamins A (1.58 to $1.92 \mathrm{ug} / 100 \mathrm{~mL}$ ) and vitamin C (25.30 to 27.79 $\mathrm{mg} / 100 \mathrm{~mL}$ ) were consistent with the results reported by Ani and Baiyeri (2008) on passion fruit juice. Vitamin C contents of $11.76,26.55$ and $35 \mathrm{mg} / 100 \mathrm{~g}$ was reported by Uchoa et al. (2008), da Silva et al. (2015) and Farias et al. (2007), respectively.

The phytochemical compositions of the juice also did not vary between the genotypes. This could further suggest that the two yellow passion fruit genotypes have genetic relationship. The values for the tannin (0.041 to 0.042 $\mathrm{mg} / 100 \mathrm{~mL}$ ), saponin $(0.982$ to $1.018 \mathrm{mg} / 100 \mathrm{~mL}$ ), phytate $(0.290$ to $0.293 \mathrm{mg} / 100 \mathrm{~mL}$ ), oxalate $(0.188$ to $0.202 \mathrm{mg} / 100 \mathrm{~mL}$ ) and phenol 0.094 to $0.095 \mathrm{mg} / 100$ $\mathrm{mL}$ ) compositions were low such that the juice can be consumed without deleterious effect on human health. Similar trends were reported by Ndukwe and Baiyeri (2016a) in the juice of Conventional and KPF-4 passion fruit genotypes previously grown with varying PM rates. Results from the study revealed low oxalate composition in the Conventional $(0.177 \mathrm{mg} / 100 \mathrm{~mL})$ and KPF-4 $(0.183$ $\mathrm{mg} / 100 \mathrm{~mL}$ ) genotypes which implied that their level in their juices are not lethal. Earlier report of Munro and Bassir (1969) noted that the lethal level of oxalate in man is $2-5 \mathrm{~g}$. The range of phytate compositions $(0.258-$ $0.345 \mathrm{mg} / 100 \mathrm{~mL}$ ) obtained in this study were lower than the range (9.22-5.72 $\mathrm{mg} \mathrm{L}^{-1}$ ) obtained by Okon and Akpanyung (2005) while working on Nigerian brands of malt. The reported range was rated as a low level and cannot result in a toxicity problem. The phytate level in this study, been lower than the previous report therefore indicates that the juice from the passion fruit genotypes are safe for consumption. The juice concentrations of tannin $(0.024$ and $0.028 \mathrm{mg} / 100 \mathrm{~mL}$ for Conventional and KPF-4, respectively) obtained in this study were very low compared to the concentrations reported for banana fruit (3.4 mg/100 g dry weight) and apple fruit ( $8.5 \mathrm{mg} / 100 \mathrm{~g}$ dry weight) juices, hence the juices will not pose health hazards. The compositions of saponin (0.908 to $1.016 \mathrm{mg} / 100 \mathrm{~mL}$ ) and phenol (0.09 to $0.098 \mathrm{mg} / 100$ $\mathrm{mL}$ ) will also not pose any health problem.

Fertilizer application significantly influenced all the proximate compositions of the yellow passion fruits. Highest juice crude protein with the application of 400 $\mathrm{kg} / \mathrm{ha} \mathrm{NPK}$ and $5 \mathrm{t} / \mathrm{ha} \mathrm{PM}+200 \mathrm{~kg} / \mathrm{ha}$ NPK could be attributed to higher accumulation and absorption of soil nitrogen aided by the addition of these fertilizers. Highest value of nitrogen $(22,800 \mathrm{mg} / 100 \mathrm{~mL})$ was recorded in this study. The application of fertilizer significantly reduced the juice crude fat implying that growing yellow passion fruit with appropriate fertilizer will further present the juice as a low cholesterol fruit juice. Passion fruit juice possess low saturated fat, cholesterol (total fat $=1 \%$ dietary value) (Condé Nast, 2018). The highest concentrations of crude fibre and total ash with the addition of $10 \mathrm{t} / \mathrm{ha} \mathrm{PM}+200$ $\mathrm{kg} / \mathrm{ha}$ NPK could be due to more supply of nutrients, availability of such minerals and higher absorption by the plants. Crude fibre aids digestion, making sure food is better absorbed while ash content is a good predictor of mineral concentration in the juice (Adeyeye and Aremu, 2017). This indicates that the combined fertilizer application provided more minerals which might have accumulated in the fruit juice. This combined fertilizer 
application, $10 \mathrm{t} / \mathrm{ha} \mathrm{PM}+200 \mathrm{~kg} / \mathrm{ha}$ NPK enhanced the accumulation of highest juice moisture which may have resulted in the dilution per given volume of juice, hence the lowest percentage juice dry matter accumulation observed with $10 \mathrm{t} / \mathrm{ha} \mathrm{PM}+200 \mathrm{~kg} / \mathrm{ha}$ NPK addition.

The combined application of organic and inorganic fertilizers significantly produced highest juice $\mathrm{K}$ and $\mathrm{Ca}$ concentrations. Earlier report by Ani and Baiyeri (2008) revealed that potassium concentration of passion fruit juice increased with increase in poultry manure rate. Magnesium concentration. Juice Mg content was significantly reduced with the application of $10 \mathrm{t} / \mathrm{ha}$ $\mathrm{PM}+200 \mathrm{~kg} / \mathrm{ha}$ NPK probably due to the antagonistic relationship between $\mathrm{K}$ and $\mathrm{Mg}$, especially with high $K$ concentration. Similar report on the antagonistic relationship of $\mathrm{K}$ and $\mathrm{Mg}$ on biochemical constituents of black tea had been documented by Jayaganesh et al. (2011). In this study, juice produced with $10 \mathrm{t} / \mathrm{ha} \mathrm{PM}+200$ $\mathrm{kg} / \mathrm{ha}$ NPK were found to possess highest concentration of potassium. The combination of 10 and $5 \mathrm{t} /$ ha PM each with $200 \mathrm{~kg} / \mathrm{ha}$ NPK also produced highest concentrations of $\mathrm{Na}$ and $\mathrm{Fe}$, respectively. However, the single addition of $20 \mathrm{t} /$ ha PM resulted in highest $\mathrm{Zn}$ content in the juice.

The juice $\mathrm{pH}$ ranged from 2.84 to 3.16 . These $\mathrm{pH}$ values are within the desirable juice $\mathrm{pH}$ value ideal to maintain juice quality during storage, according to Folegatti and Mastuura (2002). On the other hand, industrialization processes of juice are not also limited with $\mathrm{pH}$ values up to 4.2 since it gives allows greater flexibility in sugar addition. These values were in agreement with the juice $\mathrm{pH}$ value of 2.72 to 3.11 obtained by Ani and Baiyeri (2008) in the same study area. A pH value of 2.6 for fresh yellow passion fruit pulp had also been reported by Janzantti et al. (2012). Freire et al. (2014) recorded juice $\mathrm{pH}$ of 3.6 to 3.8 when grown with bovine biofertilizer. Yellow passion fruit juice, being the third most produced juice in Brazil, is widely consumed because of its high aroma and acidity (Fernandes et al., 2011). However, juice obtained from fruits produced with 400 $\mathrm{kg} / \mathrm{ha}$ NPK were most acidic. This can be attributed to inorganic fertilizer application which is promotes soil acidity.

Percentage Total Titratable Acidity (TTA) was highest (8.22) and lowest (5.93) in fruits produced with $10 \mathrm{t} /$ ha PM $+200 \mathrm{~kg} / \mathrm{ha}$ NPK and without fertilizer, respectively. The highest percentage TTA could be attributed to the humic substances and organic acids content of the applied poultry manure which may have been translocated to the fruits (Nardi et al., 2002). It has been reported that fruits with high titratable acidity are preferred by the processing industry because the artificial acidification of juice during processing are reduced (Andrade and Andrade, 2004), hence the reduction in production cost. Report by Ani and Baiyeri (2008) also revealed increased \%TTA as poultry manure rate increased.

Values of vitamin C recorded in this study (25.30 to 29.04 $\mathrm{mg} / 100 \mathrm{~mL}$ ) were higher than $21.43,15.00$ and 4.30 $\mathrm{mg} / 100 \mathrm{~mL}$ of fresh yellow passion fruit pulp as reported by Silva et al. (2015), Janzantti et al. (2012) and Genovese at al. (2008). Highest juice vitamin C concentration was produced with the application of $20 \mathrm{t} / \mathrm{ha}$ PM. This is attributable to the organic acids and sugars present in the applied poultry manure Dias et al. (2011) which were available to the plants. Dias et al. (2011) reported increased vitamin $\mathrm{C}$ content of passion fruit juice with the application of bovine bio-fertilizer. On the other hand, ${ }^{\circ}$ Brix values (9.82 to 9.30) in this study were higher than the values (1.0 to 3.0) recorded by Kaddumukasa (2017) but lower than the value of 12.0 documented by Codex Alimentarius (2005).

Reduced tannin, saponin and phytate compositions with the application of $10 \mathrm{t} / \mathrm{ha} \mathrm{PM}$ or $400 \mathrm{~kg} / \mathrm{ha}, 10 \mathrm{t} / \mathrm{ha}$ $\mathrm{PM}+200 \mathrm{~kg} / \mathrm{ha} \mathrm{NPK}$ and $10 \mathrm{t} / \mathrm{ha}$, respectively indicated that fertilization could further reduce anti-nutrients in the passion fruit juice.

\section{CONCLUSIONS}

The combined application of poultry manure and NPK fertilizers, especially $10 \mathrm{t} / \mathrm{ha} P M+200 \mathrm{~kg} / \mathrm{ha}$ NPK improved most of the juice biochemical characteristics of the two yellow passion fruit genotypes. Further studies on the combinations of other forms of organic and inorganic fertilizers are recommended.

\section{REFERENCES}

Abreu SPM, Peixto JR, Junqueira NTV, Sousa MAF (2009). Physical-chemical characteristics of five genotypes of yellow passion fruit cultivated in Basilia. Rev. Bras. Frutic. 31: 487-941.

Adeyeye EI, Aremu MO (2017). Chemical composition of the raw fruit coat, seed and pulp of passion fruit (Passiflora edulis). FUW. Trends. Sci. Technol. J. 2: 334-341.

Andrade JMB, Andrade AB (2004). Physicochemical characteristics of yellow maracuja produced in different periods in Marumbi-PR. Arch. Apa. Env.1: 391-397.

Ani JU, Baiyeri KP (2008). Impact of poultry manure and harvest season on juice quality of yellow passion fruit (Passiflora edulis var. Alavicarpa Deg.) in the subhumid zone of Nigeria. Fruits. 63: 239-247.

AOAC (2005). Official Methods of Analysis. In: Association of Official Analytical,Chemists International. (1 $8^{\text {th }}$ eds), Maryland, USA. 
Brasil (2000). Ministry of Agriculture of Supply.General technical regulation for setting identity and quality standards for fruit pulp. Official Gazette of the Federative Republic of Brazil.1: 54-58.

Bhat R, Stamminger R (2014). Impact of ultraviolet radiation treatments on the physicochemical properties, antioxidants, enzyme activity and microbial load in freshly prepared hand pressed strawberry juice. Food. Sci. Technol. Int. 21: 354-363.

Code Nast (2018). Nutrition Facts: Passion-fruit juice, yellow, raw. Self-Nutrition Data: know what you eat.

da Silva MAP, Plácido GR, Caliari M, Carvalho B de S, da Silva RM (2015). Physical and chemical characteristics and instrumental color parameters of passion fruit (Passiflora edulis Sims). Afri. J. Agric. Res.10: 11191126.

Dias TJ, Cavalcante LF, Freire JL de O, Nascimento JAM do, Beckmann-Cavalcante MZ (2011). Chemical quality of yellow passion fruit in soil with biofertilizer irrigated with salt water. Braz. Jour. Agric. Env. Eng.15: 229-236.

Farias JF, Silva LJB, Araújo Neto SE, Mendonça V (2007). Quality of yellow passion fruit marketed in Rio Branco, Acre. Rev. Caatinga. 20(3): 196-202.

Fernandes AG, Matias dos Santos G, Sales da Silva D, de Sousa PHM, Maia GA (2011). Chemical and physicochemical characteristics changes during passion fruit juice processing. Ciênc. Tecnol. Aliment. 31: 747-751.

Folegatti MIS, Matsuura FCAU (2002). Products. In: Matsuura,F.C.A.U, Folegatti M.I.S. ( $2^{\text {nd }}$ eds). Postharvested maracuja.Brasilia. 42-47p.

Freire JL de O, Cavalcante LF, Rebequi AM, Dias TJ, Brehm MA da S (2014). Quality of yellow passion fruit juice with cultivation using different organic sources and saline water. IDESIA (Chile) Enero-Febrero. 32: 79-87.

Genovese MI, Pinto MDS, Schmidt AEDS, Lajolo FM (2008). Bioactive compounds and antioxidant capacity of exotic fruits and commercial frozen pulps from Brazil. Food. Sci. Technol. Int. 14: 207-214.

GENSTAT (2007). GENSTAT Discovery Edition. Lawes Agricultural Trust (Rothamsted Experimental Station). VSN International Limited.Hemel Hempstead, UK.

Janzantti NS, Santos GC, Monteiro M (2012). Shelf life of fresh and pasteurized organic passion fruit (passiflora edulis f. Alavicarpa deg) pulp. Jour. Food. Proc. Pres. 38: 262-270

Jayaganesh S, Venkatesan S, Senthurpandian VK (2011). Impact of different sources and doses of magnesium fertilizer on biochemical constituents and quality parameters of black tea. Asian. J. Biochem. 6: 273-281.

Kaddumukasa PP, Imathiu SM, Mathara JM, Nakavuma
JL (2017). Influence of physicochemical parameters on storage stability: Microbiological quality of fresh unpasteurized fruit juices. Food. Sci Nutr. 5:1098-1105.

Maga JA (1982). Phytate: Its Chemistry, Occurrence, Food interactions, Nutritional Significance and Method of Analysis. J. Agric. Food. Chem. 30: 1-9.

Munro A, Basir O (1969). Oxalate in Nigerian vegetables. West African J. Biol. Applied. Chem. 12: 14-18.

Nardi S, Pizzeghello D, Muscolo A, Vianelo F (2002). Physiological effects of humic substances on higher plants. Soil. Biol. Biochem. 34: 1527-1536.

National Academy of Sciences (2005). Dietary Reference Intakes for Energy,Carbohydrate,Fiber,Fat, Fatty Acids, Cholesterol, Protein, and Amino Acids (Macronutrients). National Academy Press, Washington,DC,United States of America.1357p.

Ndukwe OO, Baiyeri KP (2016a). Influence of genotype and poultry manure rate on phenology and fruit yield of yellow passion fruit (Passiflora edulis f. flavicarpa Degener) in Nsukka southeastern Nigeria. Acta Horticulturae-Proceedings of 3rd All Africa Horticultural Congress held at International Institute for Tropical Agriculture. Ibadan, Nigeria.

Ndukwe OO, Baiyeri KP (2016b). Biochemical characterisation of fruit juice from two yellow passion fruit genotypes (Passiflora edulis f. flavicarpa Degener) as influenced by poultry manure rates. Acta HorticulturaeProceedings of 3rd All Africa Horticultural Congress held at International Institute for Tropical Agriculture, Ibadan, Nigeria.

OgbonnaAC, Abuajah CI, Ekpe GE (2013). Acomparative study of the nutritive factors and sensory acceptance of juices from selected Nigerian fruits. Croatian J. Food. Technol. Biotechnol. Nutr. 8: 47-51.

Okon EU, Akpanyung EO (2005). Nutrition and antinutrition in selected brands of malt drinks produced in Nigeria. Pak. J. Nutr 4: 352-355.

Orjuela BNM, Campos AS, Sánchez NJ, Melgarejo LM, Hernández MS (2011). Manual of post-harvest handling of gulupa (Passi $f$ ora edulis Sims). In: Melgarejo, LM \& Hernández MS

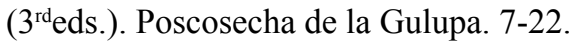

Rodríguez M, García C (2010). Postharvest, processing and nutraceutical analysis of gulupa (Passi fl ora edulis Sims.) and curuba (Passifl ora tripartita var. Mollisima). In: Memories first latin american congress of passionaries $107 \mathrm{p}$.

Silva CEF, da Silva ICC, Abud AKDS (2015). Acidulants in tropical fruit pulp: Physicochemical and sensory changes. Chem. Eng. Tran. 44: 1-6. 
Simforian E, Nonga HE, Ndabikunze BK (2015). Assessment of microbiological quality of raw fruit juice vended in Dar es Salaam city, Tanzania. Food. Control. 57: 302-307.
Uchoa AMA, Costa JMC da, Maia GA, Silva EMCS, Carvalho A de FFU (2008). Physicochemical parameters and crude and dietary fiber content of edible powders from tropical fruit residues. Separate Nutricion Nutrients.15: 58-65. 